\title{
GERTRUDE BONNIN ON SEXUAL MORALITY
}

\author{
Tadeusz Lewandowski \\ Institute of Literatures, University of Opole, Poland \\ Department of English and American Studies, \\ University of Ostrava, Czech Republic
}

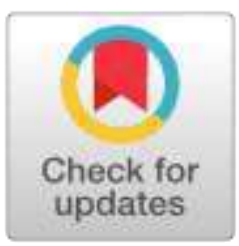

\begin{abstract}
This paper examines attitudes to sexual morality held by the Yankton Dakota author and activist Gertrude Bonnin (1876-1938), better known by her penname Zitkála-Šá (Red Bird in Lakota). Bonnin's concerns encompass several themes: the victimization of Indian women, disintegration of Native courtship rituals, sexual threats posed by peyote use, and the predatory nature of Euro-American men. This critique as a whole - in which a 'white invasion,' in her words, leads to a corruption of Native sexuality - sometimes produces inconsistencies, particularly regarding Bonnin's statements on the alleged sexual perils of peyote. Her investigations into the Oklahoma guardianship scandals of the 1920s, however, strongly buttress recent research by Sarah Deer (2015), whose study, The Beginning and End of Rape: Confronting Sexual Violence in Native America, highlights the tragic aspects of Native-white sexual relations under United States settler-colonialism.
\end{abstract}

Keywords: Gertrude Bonnin, Zitkála-Šá, Native American, Sarah Deer, sexual morality, settler-colonialism

\section{Article history:}

Received: 22 November 2020;

Reviewed: 6 December 2020;

Revised: 21 March 2021;

Accepted: 22 March 2021;

Published: 1 June 2021

Copyright (C) 2021 Tadeusz Lewandowski

This open access article is published and distributed under a CC BY-NC 4.0 International License which permits non-commercial use, distribution, and reproduction in any medium, provided the original author and source are credited. Permissions beyond the scope of this license may be available at ted.a.lewandowski@gmail.com. If you want to use the work commercially, you must first get the authors' permission.

Citation: Lewandowski, T. (2021). Gertrude Bonnin on Sexual Morality. English Studies at NBU, 7(1), 5-20. https://doi.org/10.33919/esnbu.21.1.1

Tadeusz Lewandowski, $\mathbf{P h D}$, is an American professor who teaches in the Institute of Literatures at the University of Opole, Poland, and in the Department of English and American Studies at the University of Ostrava, Czech Republic. His books include Red Bird, Red Power: The Life and Legacy of Zitkala-Ša (Norman: University of Oklahoma Press, 2016) and Ojibwe, Activist, Priest: The Life of Father Philip Bergin Gordon, Tibishkogijik (Madison: University of Wisconsin Press, 2019). He has also edited Zitkala-Ša: Letters, Speeches, and Unpublished Writings, 1898-1929 (Boston, Lieden: Brill, 2018).

E-mail: ted.a.lewandowski@gmail.com

https://orcid.org/0000-0002-9067-2403 


\section{Brazen love-petting exhibitions}

Sex is not a subject commonly associated with the Yankton Dakota writer and activist Gertrude Simmons Bonnin (Zitkála-Šá). Nonetheless, the dangers of 'brazen love-petting exhibitions,' as she once purportedly referred to intercourse, make up a prominent theme in her public activism, private letters and statements, and political pamphlets such as The Menace of Peyote (1916) and Oklahoma's Poor Rich Indians (1924) (Hanson, p. 70). Bonnin's distaste for sex outside of church-sanctioned marriage, for instance, became a central motivating factor in her quest to establish a Catholic church at Uintah Reservation in the 1910s. Moreover, her anti-peyote campaign of roughly the same period sought to ban a substance that, she claimed, 'excite[d] the baser passions' and encouraged the sexual exploitation of Native women (Hearings before the Senate Subcommittee of the Committee of Indian Affairs of the House of Representatives on H.R. 2614, p. 125). Bonnin's condemnation of predatory sexuality also appears in her investigations in Oklahoma, where, in 1923-24, she directly linked the assault of Native women and girls by white grafters to greed for Indian land and resources. This last aspect of Bonnin's critique bears similarities to recent research by the Muscogee attorney Sarah Deer, whose The Beginning and End of Rape: Confronting Sexual Violence in Native America (2015) details the grave threats faced by Native women and girls in the Americas from the beginnings of the colonial era, when new legal systems 'protected (and rewarded) the exploiters [and] therefore encouraged the institutionalization of sexual subjugation' (p. 62). Though Gertrude Bonnin left no dissertation as lengthy, complex, or well researched as Deer's, one can identify several foundations in her discourse of sex under settler-colonialism. Bonnin consistently promotes the exclusivity of intimate relations to Christian marriage as a standpoint from which to criticize both Native and Euro-American sexual immorality; yet in other contexts she employs a vision of past Native rectitude to censure the influence of sexually depraved white males, who, she argues, have encouraged a debauchery unknown to Indians before European contact. This claim that the 'white invasion,' as she puts it, is wholly responsible for the corruption of Native sexuality elides, in particular, inconsistencies in Bonnin's own statements on the alleged sexual perils of peyote use (Hanson, p. 70). Her work in Oklahoma, nevertheless, strongly buttresses conclusions presented in Deer's research. 


\section{Biographical sketch}

Born in 1876 on the Yankton Reservation, Dakota Territory, to Ellen Taté I Yóhin Win Simmons and a delinquent white father, Gertrude Simmons Bonnin grew up at a time when the U.S. federal government was pursuing a policy of assimilation for Native peoples through white education. Gertrude was around eight when she left her mother's tepee for White's Manual Labor Institute, a government-funded, Quaker-run boarding school in Wabash, Indiana. There, from 1884 to 1895, she completed two terms of schooling that resulted in a profound cultural alienation from her mother and her old life at Yankton. In 1895, she was accepted to another Quaker institution, Earlham College, in Richmond, Indiana, where she studied music and excelled in oratory, even placing second in the Indiana State Oratorical Competition in 1896. Though she did not earn a diploma due to illness, Gertrude later secured a position at the Carlisle Industrial Indian School in Pennsylvania, then the premier off-reservation boarding school in the United States. She soon after came to detest the school's atmosphere, and question its assimilationist mission. In 1899, Gertrude moved to Boston to pursue studies in violin, but instead gained recognition for a series of semi-autobiographical exposés on Indian boarding schools for the Atlantic Monthly (1900), which she signed Zitkála-Šá (Red Bird, in Lakota). Shortly after, she returned to the Dakotas, hoping to reconnect with her mother and her birth culture. In late 1901, Gertrude published Old Indian Legends, a volume of traditional Lakota stories. Around this time, she met and married Raymond Telephause Bonnin, an Indian Service employee whose work took the couple to the Uintah and Ouray Reservation in Utah, home to the Northern Ute Nation, in 1902 (Davidson and Norris, 2003, pp. xiv-xx).

At Uintah, the Bonnins welcomed their first and only child, Ohiya (Winner), in 1903, and did their best to aid the Ute community amidst circumstances of poverty and corruption. The family spent the winter of 1909/10 at Standing Rock Reservation in the Dakotas. At Fort Yates, the administrative center, Gertrude became involved with the local Benedictine Catholic Mission, which, in her estimation, did 'wonderful work' for the local Lakota community (Bonnin to William H. Ketcham, May 25, 1910). Father Martin Kenel, one of the mission's key figures, befriended Gertrude, and under his tutelage she converted, quite zealously, to Catholicism (Lewandowski, 2016, p. 70). 
When the Bonnins returned to Uintah, Gertrude began an artistic collaboration with a Mormon music teacher, William Hanson, co-composing The Sun Dance Opera (1913), a mixture of Lakota melodies and western musical conventions based on the Plains Indian Sun Dance religious ceremony (Hafen, 2001, p. xix). In the 1910s, she became increasingly engaged in political organizing, joining the Native-run reform group, the Society of American Indians (SAI) in 1914, and becoming secretary in 1916. After witnessing the spread of peyote use at Uintah, Gertrude began a multi-state, antipeyote campaign, partnering with temperance groups to ban trade and ingestion of what she considered a dangerous drug. In 1917, deepening participation in Indian activism took the Bonnins to Washington, D.C., where Gertrude expanded her antipeyote campaign, advocated for Indian citizenship, and largely took over the Society of American Indians. She quit the organization in 1919 upon the election of a pro-peyote president (Lewandowski, 2016, pp. 13-14, 155).

Disappointed but hardly defeated, Gertrude Bonnin continued her activism with the Christian General Federation of Women's Clubs (GFWC), and published the collection American Indian Stories (1921), and Americanize the First American (1921), a pamphlet that outlined a road map for eventual tribal self-determination. In 1923-24, with the support of the Indian Rights Association and American Indian Defense Association, she investigated crimes against Oklahoma's Five Civilized Tribes by the state's political and business establishments, which sought to profit from oil-rich Indian lands. Having completed apprenticeships in larger reform organizations, Bonnin founded the National Council of American Indians (NCAI) in 1926. During its existence, the NCAI made lengthy investigative trips to reservations across the United States, while representing indigenous Nations in Washington (Davidson and Norris, 2003, pp. xxvii-xxviii). Sadly, her final years were spent in relative poverty, believing that her work on behalf of Native rights had been largely futile. When Gertrude Bonnin died in 1938, the NCAI collapsed. She herself was quickly forgotten. (Lewandowski, 2016, pp. 184-87). Bonnin was only rediscovered in the 1980s, when her writings were reissued by University of Nebraska Press. Since that time, scholars have produced voluminous commentary on her Atlantic Monthly semi-autobiography and other works (Lewandowski, 2019, pp. 33-34). Bonnin's views on sexual relations, however, have never received sustained, concentrated scrutiny. 


\section{Sex and settler-colonialism}

Examining Gertrude Bonnin's attitudes to sex is, admittedly, not the first path of inquiry that springs to mind when studying her life as a writer and activist. And in truth, she left few explicit statements on her views. As a result, this brief exploration is hampered by the lack of a detailed record of Bonnin's thoughts. Still, there exists enough material in her letters, writings, reminiscences, Congressional testimony, and even her Sun Dance Opera, to re-construct her stances and draw conclusions relevant to the ways Native-white sexual relations and sexual violence against indigenous women have affected Indian societies overwhelmed by U.S. settler-colonialism.

In her recent book, The Beginning and End of Rape: Confronting Sexual Violence in Native America, Sarah Deer (2015) demonstrates how, since colonial times, EuroAmerican law has 'encouraged the institutionalization of sexual subjugation' of Native women (p. 62). The result, Indian slavery, was a de facto institution in the nineteenth century that enabled sexual transgressions against Native women. At the center of these injustices lay a clash of cultures. Euro-American-and especially Victorian-era-sexual norms ran up against Native perspectives of what constituted healthy sexual practice. This stark contrast meant that Native women who engaged in consensual love-making were, as a group, penalized for failing 'to adhere to Western standards of femininity.' As the settler-colonialist regime evolved, the rape of indigenous women, particularly by white men, 'was not truly considered rape and received little (if any) response from the legal system' (p. 64). Seeking justice in such cases was near impossible. Coupled with this gross legal imbalance was the commoditizing of marriage. Toward the end of the nineteenth century, the 1887 Dawes Act, which allotted communally-owned reservation lands to individuals in severalty, began to make landowners of Indian women. Landowner status, however, often made women the targets of white male suitors determined to usurp valuable property. White husbands, protected by a patriarchal legal system, could mistreat or abandon their Native wives with impunity (p. 65-67).

One prominent case of widespread sexual abuse of Native women that Deer does not discuss in her book is 1920s Oklahoma, setting of a short-lived oil boom. There, white men established a system of Indian guardianship through the court system, intended to gain control over profits from resource-rich lands. In the absence of any legal checks, such male 
guardians employed rape and even murder to subjugate female Native property owners, with tragic regularity. Gertrude Bonnin had direct involvement in investigating these crimes in 1923-24, though this was hardly her first campaign against sexual exploitation (Bonnin, Fabens and Sniffen, 1924, pp. 23-28, 37; Wilson, 1985, pp. 137-47). Instead, concerns over the exploitation of Indian women and girls had long inspired her activism.

\section{Sexual morality and The Sun Dance Opera}

Gertrude Bonnin's conversion to Catholicism at Standing Rock Reservation in 1909/10 inaugurated a new (or at least newly expressed) preoccupation with Native sexuality, which took written form following her return to Uintah in 1910 (Lewandowski, 2016, p. 70). Once re-settled, she began correspondences with Father Kenel and his colleague, Father William H. Ketcham, director of the Bureau of Catholic Indian Missions. Here, the dangers of pre- and extra-marital sex became a semi-regular trope. In early 1911, she wrote Ketcham to complain that the Utes at Uintah had fallen into a state of deep degradation. Not only did they lack 'interest in spiritual life,' they were 'immoral.' While drinking and gambling were listed among their sins, sexual relations unauthorized by the church posed the greatest threat to potential salvation. The Utes' marriages, regrettably, were 'not legal' (Bonnin to Ketcham, January 29, 1911). Bonnin's anxiety over such issues was, in some cases, arguably legitimate. 'Again,' she wrote Ketcham in May of the same year, 'one of the Agency Policemen has been living with a little girl, who is not 12 years old, as his wife.' The policeman (not identified as white or Native) had since been fired, but the case was proof of 'the very sad condition of these Utes' (Bonnin to Ketcham, May 28, 1911). Bonnin deployed these mentions of sexual impropriety for a specific, activist purpose. She meant to convince Ketcham to open a Catholic mission at Uintah, so the Utes could ultimately be converted and reformed (Lewandowski, 2016, p. 75).

To a degree, Bonnin's complaints could be dismissed as middle-class moral angst, or perhaps religio-centrism. But when looking at the larger picture of life at Uintah, one is better able to comprehend her dismay, and why she-a freshly-minted, ardent Catholic-sought a religious salve. Bonnin's friend and collaborator on The Sun Dance Opera, William Hanson (1967), provides a stark portrait of the reservation in his memoir, Sun Dance Land. The book describes Fort Duchesne, the agency center, as a 'Hell Hole' populated by drunken soldiers on the lookout for prostitutes. The town's main street, 
called the 'Strip,' even includes a cemetery in which every single occupant has been murdered. More relevantly, Sun Dance Land gives us insight into Bonnin's views on Native sexual relations in an era of white domination. Hanson states that in public lectures, Bonnin 'boldly condemned the American people for the constant use of force and intrigue in the conquest of the red-man-inherited and occupied territory.' She as well 'extolled the deep-seated national emotions and dreams [of her] people,' while venerating the 'old time culture' of her 'forefathers.' Key to her perspective was the insistence that Native peoples 'did not know immorality until after the white invasion.' By 'immorality,' Bonnin meant sex outside marriage. 'Courting among lovers was modest,' she asserted, 'controlled by selective customs; and was not accompanied by the brazen love-petting exhibitions so often seen today.' In her view, Natives had been despoiled, victims to EuroAmerica's 'alcohol curse, tuberculosis, syphilis and immorality, greed, broken promises and discarded treaties' (pp. 62,69-71). The result was a mire of demoralization.

Yet as recorded in Sun Dance Land, Bonnin's linking of the 'white invasion' to the 'brazen love-petting exhibitions so often seen today' lacks specificity. A contemporary of hers, the Oglala Lakota chief, writer, and actor Luther Standing Bear, however, may shed greater light on Bonnin's thought process. Standing Bear's 1933 book, Land of the Spotted Eagle (2006), discusses the modesty of Lakota women and men, their elaborate courtship and marriage customs, and the negative influence posed by whites. He writes that 'fidelity' in marriage was an 'Indian virtue to become weakened by the disruption of his society, for the white man was wont to take the things that pleased him' (p. 163). This transformation from virtue to vice, as in Bonnin's statement, stemmed from a generalized demoralization brought about through contact with poor examples of conduct. Why Bonnin's solution lay in the adoption of Catholicism rather than a return to Native values, as expressed in Hanson, is unclear. Perhaps she saw Catholicism's sexual morals as compatible with those of the pre-contact past, making them the best model for the future.

Whatever the case, sexual impropriety was certainly on Bonnin's mind when she co-composed The Sun Dance Opera in the early 1910s. Seen through this lens, the opera's plot becomes a reflection of what she viewed as proper and improper Native courtship. In the setting of the pipestone quarries near Yankton, a disgraced Shoshone named Sweet Singer, who has stolen 'sacred love leaves' from a medicine man, attempts to seduce the maiden Winona. The heroic Lakota Ohiya, also in love with Winona, warns her of Sweet 
Singer's ill intentions and stresses that 'Love is valor, not empty words.' Sweet Singer is meanwhile pursued by a Shoshone woman who has tragically 'fled the rule of modesty' by succumbing to his advances (Hafen, 2001, pp. 131-32, 144). Ohiya eventually wins Winona's hand by courting her in the traditional manner, with a wooden flute, then by taking part in the Sun Dance ceremony to demonstrate his sincerity and stamina. At the opera's climax, Sweet Singer expediently disappears with the 'Witches of the Night,' as all celebrate the triumph of Ohiya's moral virtue. While in fact the Sun Dance was never performed to impress women, Sweet Singer's use of the aphrodisiac 'sacred love leaves' presciently suggests Bonnin's crusade against peyote ingestion at Uintah, which was soon to begin (Smith, 2001, pp. 11-12).

\section{The (sexual) menace of peyote}

Gertrude Bonnin's preoccupation with Ute sexual morality intensified greatly approximately a year after The Sun Dance Opera premiered. In 1914, an Oglala Lakota named Sam Lone Bear appeared in Dragon, Utah, preaching the benefits of peyote. Lone Bear was born in 1879 on Pine Ridge Reservation, South Dakota, and remained there until at least 1910 (Friesen, 2017, pp. 68, 71). When he later arrived in Uintah, Lone Bear impressed the local Ute population with his personal magnetism. A local man, Dick Sirawap, allowed Lone Bear to live with his teenage daughters, Ella and Sue, whom he impregnated. One gave birth as early as age thirteen. Lone Bear also looked elsewhere for pleasure. While still staying with Sirawap, he persuaded a teenage girl, Mary Guerro, to follow him to Nebraska. Once there, he kept her confined as a sexual prisoner, impregnated her, and abandoned her. Though Lone Bear was subsequently jailed by Utah authorities, no one would testify against him and he went free (Stewart, 1987, pp. 17879, 197-201; Simmons, 2000, pp. 241-42). ${ }^{1}$ Such bald chicanery and sexual exploits immediately made him a target of Bonnin's ire, and in part prompted her to campaign

\footnotetext{
1 Sam Lone Bear's identity has been mistaken for decades. Omer Stewart (1987), in Peyote Religion: A History, first misidentified Lone Bear as a Carlisle student from Pine Ridge who posed for photographer Gertrude Käsebier and later traveled with Buffalo Bill Cody's Wild West Show to Europe. Instead, there were two Sam Lone Bears from Pine Ridge, the other of whom was the Peyotist and criminal. This confusion was only brought to light with the publication of Steve Friesen's (2017) Lakota Performers in Europe: Their Culture and the Artifacts They Left Behind. Eventually, Lone Bear the criminal ended up serving two years in federal prison, on McNeil Island in Washington state, from 1933 to 1935. He died in 1937 at Pine Ridge (pp. 68, 71-73).
} 
against peyote's use. To her, Lone Bear quickly became the embodiment of Indian sexual devolution in the modern era.

Lone Bear first attracted Bonnin's attention after he convinced an influential Ute chief, John McCook, that peyote could sooth his rheumatism, causing ingestion of the cactus to spread rapidly (Bonnin to Arthur C. Parker, November 11, 1916). By mid-1915, approximately fifty percent of the Northern Utes had begun using peyote in regular gatherings (Simmons, 2000, pp. 241-43). Bonnin was horrified by this growing peyote use and Lone Bear himself, who, along with continuing his sexual exploits, regularly cheated Utes of their money selling tokens that purportedly possessed supernatural powers (Stewart, 1987, pp. 178, 200-01; Hearings before the Senate Subcommittee of the Committee of Indian Affairs of the House of Representatives on H. R. 2614, 1918, pp. 125-26). To eradicate Lone Bear and his peyote from Uintah and elsewhere, Bonnin began a multi-state effort to engage groups such as the Women's Christian Temperance Union throughout the West, in Colorado, Nevada, and Utah (Lewandowski, 2016, p. 108). These actions against peyote have often been derided by scholars, cast as a Christian, assimilationist scheme to destroy a burgeoning Native religion (Slotkin, 1956, pp. 47, 121; Warrior, 1995, pp. 4, 10, 13-14; Willard, 1991, pp. 25-30). Such charges, however, amount to an inaccurate simplification. Bonnin saw no religious aspect in peyote's ingestion, and, based on all available evidence, any explicit motive of proselytizing for Christianity was not her immediate goal in banning the substance (Lewandowski, 2016, p. 143).

A full accounting of Bonnin's anti-peyote campaign is outside the scope of this paper. Instead, what is relevant here is how she directly linked sexual immorality to peyote use. That said, it is deeply unfortunate that none of the many speeches Bonnin delivered against peyote have survived. As a result, we do not have her on record explicitly and repeatedly connecting peyote and sexual licentiousness before the women's and temperance groups she addressed in the mid-1910s. However, when reading her public statements from 1918, we can assume with great confidence that she consistently highlighted the issue of sex. Her The Menace of Peyote (1916) details the alleged physical and mental dangers of the cactus, which she compares to alcohol—often a bane among Indian populations. 'Men, women,

\footnotetext{
2 Davidson and Norris date Bonnin's anti-peyote pamphlet from 1916. However, The Menace of Peyote includes references to Bonnin's testimony before a House subcommittee in 1918 (p. 239). This may have been a later version of the pamphlet.
} 
and children on Indian reservations attend weekly peyote meetings every Saturday night to eat peyote,' the pamphlet explains, 'It takes all Sunday to recover somewhat from the drunk. Too often in their midnight debaucheries there is a total abandonment of virtue' (Quoted in Davidson and Norris, 2003, p. 240). That Bonnin mentions 'children' is likely no accident, but a tactic used to attract more attention to her cause. It probably worked. Peyote's ostensible encouraging of the 'total abandonment of virtue' among all ages appears as the main theme in much of her anti-peyote activism.

In 1918, Bonnin testified before the House subcommittee of Indian Affairs on the peyote issue in hearings meant to decide the fate of a bill introduced by Arizona congressman Carl Hayden, who had proposed a nationwide ban (Lewandowski, 2016, pp. 118, 136, 141-43). The week she appeared before Congress, Bonnin spoke with a Washington Times reporter at length. The paper published her statements in a featured article, "Indian Woman in Capital to Fight Growing Use of Peyote Drug by Indians," on February 17, 1918. The piece, while expounding on the 'mental and physical evils' of peyote, described ceremonies as all-night 'feasts' marked by 'the wildest intoxication and all kinds of orgies in which men, women, and even children take part to the degradation of their minds.' The term 'orgy' may not have been used in an exclusively sexual sense, but instead employed to underline the 'wild' nature of the meetings. Bonnin did nonetheless stress that peyote abolished 'all moral restraint' when 'used in a way which outrages decency and induces intoxication and degeneracy' (p. 9). Any lack of clarity surrounding the 'orgy' issue was eliminated in Bonnin's subsequent testimony before the House committee. At a climactic moment, she described an alleged rape committed by Sam Lone Bear, who had fed his victim, a young woman, a peyote button. Consent was at the heart of the matter. Peyote, in Bonnin's telling, could 'excite the baser passions,' thereby inducing Native women to forgo reticence and behave in ways they normally would not (Hearings before the Senate Subcommittee of the Committee of Indian Affairs of the House of Representatives on H. R. 2614,1918, pp. 124-26). This moral danger was one of the main justifications for implementing a federal ban.

Bonnin's statements in Washington indicate how her anti-peyote campaign was in large part concerned with countering sexual predation, rather than fostering assimilation. One might argue that she did promote assimilation to Christian / Catholic / Victorian sexual norms, but as recorded by William Hanson in Sun Dance Land, Bonnin's desire for 
a return to pre-contact Native sexual morals could likewise explain her objections to peyote, which she directly associated with Sam Lone Bear's manner of perfidy. Her testimony did, however, include remarks on religion. When questioned on the subject, Bonnin responded, 'I suppose [Christians] would be against [peyote] on the ground that they would oppose anything that was demoralizing. I do not believe...that this opposition can be represented as being made because of a difference in religions. It is not that, because even Indians who are Christians become addicted to the habit of using peyote.' To her, peyote was something akin to alcohol-'twin brothers,' as she called them. As a result, it had to be stamped out to protect the family unit from 'undermining work,' and to shield Native women and girls from its distorting effects on sexual propriety (pp.128-30).

Nonetheless, Bonnin had to have been at least somewhat aware that there was irony, not to mention a lack of historical and even contemporary context, in her attacks on peyote-all of which undercut her arguments against the cactus, and for her claim of the exclusively white-induced deterioration of Native sexual morality. Although peyote was new to Uintah, it had been ingested in the Americas for millennia. The Spanish first recorded its use among the Chichmeca in present-day Mexico in the 1600s, while the Coahuitec, Hopi, and Taos in the American Southwest had also used peyote for both healing and spiritual purposes, dating back to the seventeenth century. The Peyote Religion, which Bonnin sought effectively to ban, had developed at the end of the nineteenth century among Plains Indians such as the Wichita, Comanche, and Kiowa. In organized rituals that combined elements of Christianity with Native beliefs, such peoples sought to rectify through spirituality the effects of white colonialism by creating intertribal solidarity. This form of the Peyote Religion eventually became prominent among the Navaho, Winnebago, Paiute, and to a degree the Lakota, as a peaceful countermovement that preserved ancient beliefs, and strove to locate goodness within white oppressors (Lanternari, 1963, 65-67, 97-100). Many of the new adherents were graduates of Indian boarding schools, and considered themselves Christian. At a Society of American Indians conference in 1916, one Kiowa delegate, Delos Lone Wolf, even argued that peyote had enabled him not only to discourage alcohol consumption, but convert members of his tribe to Christianity after years of failed attempts by missionaries (Herzberg, 1971, pp. 149-50, 280-81). 
But if Bonnin ignored, or chose to ignore, the greater question of the Peyote Religion, its intricacies, and peyote's long and significant history among Native peoples, she may have found it harder to pass over the fact that this ostensibly corrupting force had been promoted not by whites, but by Indians. In the spring of 1917, Bonnin gave an anti-peyote lecture at California's Sherman Institute, and Indian boarding school. The Friends' Intelligencer, the largely Quaker-run Indian Rights Association's journal, deemed her speech (which has not survived), a 'very impressive address' in its detailing of 'the degenerating effect of the death-dealing Peyote' (Burgess, 1917, 313). Interestingly, Bonnin apparently refused to implicate, explicitly, Indians in peyote's spread. Instead, she blamed vaguely labeled 'people' for trafficking peyote on reservations, rather than Native peoples themselves, or even Sam Lone Bear (Newmark, 2012, 328). Placing such blame would have naturally undermined her larger discourse of white corruption of Native morals; perhaps, then, figures like Lone Bear merely represented the carnal depths to which Native peoples could sink under the wrong kind of influence.

\section{Oklahoma}

Whatever inconsistencies or contradictions might arise in Gertrude Bonnin's recorded statements on sex from the 1910s, her critique becomes much more powerful as her activism continues into the 1920s. In 1923, Bonnin, with the American Indian Defense Association and the General Federation of Women's Clubs, began investigating ongoing crimes against the Five Civilized Tribes in Oklahoma, which had fallen prey to all measure of schemes by white businessmen and government officials attempting to appropriate profits from oil-rich lands. Under a system of court guardianship, white grafters were able to divest thousands of Natives of their wealth, 'managing' their assets while sometimes exploiting their wards to the point of death. As recorded by Angie Debo (1940) in her seminal work, And Still the Waters Run, the 'plundering of children' left Native minors subject to kidnapping and rape at the hands of white men-incidents entirely representative of the history of sexual abuse presented in Deer's (2015) The Beginning and End of Rape (p. 103). In late 1923, Bonnin, along with attorney Charles H. Fabens and Indian Rights Association representative Matthew K. Sniffen, conducted a five-week inquiry into these ongoing crimes. The result was Oklahoma's Poor Rich Indians: An Orgy of Graft and Exploitation of the Five Civilized Tribes-Legalized Robbery 
(1924), a pamphlet that exposed horrific cases of Euro-American assault on indigenous women and children.

In Oklahoma's Poor Rich Indians, Gertrude Bonnin writes on, as Fabens and Sniffen put it, 'phases of our investigation that can be presented best by a feminine mind.' This means, precisely, two cases in which white guardians abducted and raped young women. Bonnin discusses the case of a Creek girl, Akey Ulteeskee, kidnapped at age four and, over time, forced to bear her guardian's child. Now an adult, abandoned and robbed of thousands, Ulteeskee lived on a mere five dollars a month awarded her by the courts as parcel of her oil monies. Bonnin also focuses on the story of Millie Neharkey, once owner of lands worth $\$ 150,000$. A group of men connected with the Gladys Belle Oil Company abducted Neharkey on her eighteenth birthday, and raped her repeatedly over the course of several days. At the conclusion of the ordeal, Robert F. Blair, the group's leader, forced Neharkey to sell Gladys Belle her lands for a mere fraction of their worth. Bonnin describes her meeting with Neharkey, noting 'her smallness of stature, her child's voice and her timidity,' and how she is 'decidedly immature.' The girl's 'little body,' she adds, had been 'mutilated by a drunken fiend who assaulted her night after night' (pp. 23, 25-26).

Though Bonnin's contribution to Oklahoma's Poor Rich Indians is one of the major works of her activism, few scholars have commented upon it. One that has is Patrice Hollrah. Hollrah (2004) points out how Bonnin uses 'the language of sentimentalism' to add 'pathos' and 'persuasive power' to her stories. She also observes how Bonnin does not present Neharkey as a woman, but a 'little girl' whose 'little body' has been 'mutilated,' making the description of the rape into a consciously sentimental 'seduction narrative' meant to move middle-class female reformers to action (pp. 48-50). One may question this assertion. While Bonnin, in her discussions of peyote 'orgies,' possibly included children as a tactic to gain attention, the stories of rape in Oklahoma's Poor Rich Indians require no enhancement.

Bonnin's findings in Oklahoma prompted hearings by the House Committee on Indian Affairs, initiated by the Chickasaw Oklahoma Representative Charles D. Carter. Carter, unfortunately, was not seeking justice. At the hearings, the congressmen involved, New York Representative Homer Snyder prominent among them, famously sought to whitewash the crimes committed and reject any evidence provided, all to exonerate 
Oklahoma as a state (Lewandowski, 2016, pp. 169-70). It remains striking how Bonnin's detailing of rape failed to convince any of these congressmen to take any measures against Oklahoma guardianships, or investigate cases of abuse against Native women and children. It is reasonable to assume that evidence of widespread sexual crimes against white American women concentrated in any given state would have triggered an immediate reaction on the part of lawmakers. But as Sarah Deer (2015) notes, the rape of Native women by white men, historically, 'was not truly considered rape and received little (if any) response from the legal system' (p. 64). This double standard for sexual crimes against Native and white women, we can infer, was certainly at play in Oklahoma. Yet despite its failure to effect change, Oklahoma's Poor Rich Indians is by far the strongest of Bonnin's works to offer criticism of Native-white sexual relations under settlercolonialism.

\section{Hypocrisy and violence}

While this article's brief examination of Gertrude Bonnin's thoughts on sexual morality is hindered by the lack of any explicit dissertation, some conclusions can be reached. Bonnin's fears over sexual immorality and exploitation, without question, informed important aspects of her activism-whether in trying to establish a Catholic church at Uintah, in advocating for a ban on peyote, or in exposing the unconscionable offences of Oklahoma guardianship. Concerning her distinct views on Native sexuality in an era of Euro-American dominance, there appear several main themes: the exploitation of Native women and, especially, girls, the disintegration of Native courtship rituals, the alleged sexual threats posed by peyote use, and the predatory nature of white male sexuality. As a salve, Bonnin promoted the exclusivity of intimate relations to churchordained, Christian marriage, which she saw as equivalent to stable unions preceded by traditional Native courtship rituals. Disruption of the latter resulted from the negative influence of white males, who had, in her estimation, despoiled Native peoples in a manner unknown in the pre-contact past. Bonnin's Oklahoma's Poor Rich Indians, finally, exposes extreme examples of white sexual predation linked to rank avarice for Indian lands and resources, as meticulously documented in Sarah Deer's The Beginning and End of Rape. This culmination of Gertrude Bonnin's critique-if not its entirety-bears testament to a Euro-American sexual culture marked by hypocrisy and violence, and continues to resonate loudly today. 


\section{References}

Bonnin, G. (Zitkála-Šá), Charles H. Fabens, and Matthew K. Sniffen. (1924). Oklahoma's Poor Rich Indians: An Orgy of Graft and Exploitation of the Five Civilized Tribes, Legalized Robbery. Washington, D.C.: Office of the Indian Rights Association.

Bonnin, G. (1916). The Menace of Peyote. In Cathy N. Davidson \& Ada Norris (eds.), Indian Stories, Legends, and Other Writings, 239-41. New York: Penguin Books, 2003.

Bonnin, G. (1916) Letter to Arthur C. Parker, November 11. The Papers of the Society of American Indians, edited by John Larner. Wilmington: Scholarly Resources, 1986.

Bonnin, G. (1911). Bonnin to Ketcham, May 28. Bureau of Indian Catholic Missions, Raynor Memorial Libraries, Marquette University.

Bonnin, G. (1910). Bonnin to Ketcham, May 25. Bureau of Indian Catholic Missions. Raynor Memorial Libraries, Marquette University.

Bonnin, G. (1911). Letter to Ketcham, January 29. Bureau of Indian Catholic Missions. Raynor Memorial Libraries, Marquette University.

Bonnin, G. (1900). Impressions of an Indian Childhood. Atlantic Monthly 85(1), 37-47.

Burgess, M. (1917). Zitkála-Šá (Red Bird). Friends' Intelligencer May 19, 313.

Davidson, C. N. and A. Norris, eds. (2003). American Indian Stories, Legends, and Other Writings. New York: Penguin Books.

Debo, A. (1972). And Still the Waters Run: The Betrayal of the Five Civilized Tribes. Princeton: Princeton University Press.

Deer, S. (2015). The Beginning and End of Rape: Confronting Sexual Violence in Native America. University of Minnesota Press. https://doi.org/10.5749/minnesota/9780816696314.001.0001

Friesen, S. (2017). Lakota Performers in Europe: Their Culture and the Artifacts They Left Behind. Norman: University of Oklahoma Press.

Hafen, P. J., (Ed.) (2001). Dreams and Thunder: Stories, Poems, and The Sun Dance Opera. Lincoln: University of Nebraska Press.

Hanson, W. (1967). Sun Dance Land. Provo: J. Grant Stevenson.

Hearings before the Senate Subcommittee of the Committee of Indian Affairs of the House of Representatives on H. R. 2614 to Amend Sections 2139 and 2140 of the Revised Statutes and the Acts Amendatory thereof, and for Other Purposes. (1918). Washington: Government Printing Office. 
Hertzberg, H. (1971). The Search for an American Indian Identity: Modern Pan-Indian Movements. Syracuse: Syracuse University Press.

Hollrah, P. E. M. (2004). Old Lady Trill, the Victory Yell: The Power of Women in Native American Literature. Routledge. https://doi.org/10.4324/9780203507834

Indian Woman in Capital to Fight Growing Use of Peyote Drug by Indians. (1918). February 17, Washington Times.

Lanternari, Vittorio. (1963) The Religions of the Oppressed: A Study of Modern Messianic Cults, trans. Lisa Sergio. New York: Mentor Books.

Lewandowski, T. (2019). Changing Scholarly Interpretations of Gertrude Bonnin (Zitkála-Šá). Atlantis: Journal of the Spanish Association for Anglo-American Studies 41(1), 31-49. https://doi.org/10.28914/Atlantis-2019-41.1.02

Lewandowski, T. (2016). Red Bird, Red Power: The Life and Legacy of Zitkála-Šá. Norman: University of Oklahoma Press.

Newmark, J. (2012). Pluralism, Place, and Gertrude Bonnin's Counternativism from Utah to Washington, D.C. American Indian Quarterly 36(3), 318-47. https://doi.org/10.5250/amerindiquar.36.3.0318

Simmons, V. M. (2000). The Ute Indians of Utah, Colorado, and New Mexico. Boulder: University of Colorado Press.

Slotkin, J. S. (1956). The Peyote Religion: A Study in Indian White Relations. Glencoe: The Free Press.

Smith, Catherine Parsons. (2001). An Operatic Skeleton on the Western Frontier: Zitkála-Šá, William F. Hanson, and The Sun Dance Opera. Women and Music 5, 130.

Standing Bear, L. (2006). Land of the Spotted Eagle. Lincoln: Bison Books.

Stewart, O. C. (1987). Peyote Religion: A History. Norman: University of Oklahoma Press.

Warrior, R. A. (1995). Tribal Secrets: Recovering American Intellectual Traditions. Minneapolis: University of Minnesota Press.

Willard, W. (1991). The First Amendment, Anglo-Conformity and American Indian Religious Freedom. Wicazo Sa Review 7, 25-30.

https://doi.org/10.2307/1409325

Wilson, T. P. (1985). The Underground Reservation: Osage Oil. Lincoln: University of Nebraska Press.

\section{Reviewers:}

1. Anonymous

2. Anonymous
Handling Editor:

Stan Bogdanov, PhD

New Bulgarian University 